\title{
PENGARUH KEKUATAN OTOT LENGAN DENGAN KELINCAHAN TERHADAP KETEPATAN SMASH BOLA VOLI PADA CLUB ANEKA
}

\author{
Wildan Qohhar ${ }^{1}$, Beni Setiawan ${ }^{2}$ Sandi $^{3}$ \\ ${ }^{1}$ Program Studi PJKR STKIP Situs Banten, Indonesia \\ E-mail : wildan.qohhar@stkipsitusbanten.ac.id
}

\begin{tabular}{l}
\hline Info Artikel \\
\hline Sejarah Artikel: \\
Diterima Juli 2019 \\
Disetujui Oktober 2019 \\
Dipublikasikan Desember 2019
\end{tabular}

\begin{abstract}
Abstrak
Tujuan yang ingin dicapai dalam penelitian ini adalah untuk mengetahui apakah ada pengaruh kekuatan otot lengan dengan kelincahan terhadap ketepatan smash dalam bola voli pada club aneka di cilegon, sedangkan sampel pada penelitian ini yaitu sebanyak 15 atlet yang terdiri dari 15 putra, teknik sampling yang digunakan yaitu sampel jenuh. Desain penelitian menggunakan pretest - posttest control group desain. Instrument yang digunakan yaitu mengukur ketepatan smash. Hasil penelitian ini menunjukan bahwa ada pengaruh kekuatan otot lengan terhadap ketepatan smash diperoleh thitung $8.256>$ ttabel 2.145 dan nilai signifikasi $0.000<0.05$ Maka dari hasil penelitian ini dapat disimpulkan bahwa kekutan otot lengan lebih berpengaruh dibandingakn dengan kelincahan terhadap ketepatan smash dalam bola voli pada club aneka di Cilegon. Dengan demikian untuk mendapatkan ketepatan smash yang baik dalam berlatih ataupun bertanding harus disertai dengan latihan kekuatan otot lengan.
\end{abstract}

Keyword:

Peningkatan Latihan

Kekuatan Otot Lengan

Abstract

Servis Atas Bola Voli

The goal to be achieved in this study is to find whether there is an influence of arm muscle strength with agility on the accuracy of volleyball smashe at aneka clubs in cilegon while the samples in this study were 15 athletes consisting of 15 men, the sampling technique used is saturated samples. The design of this study uses pretest - posttest control group desain. The instrument used is smash accuracy test. The results of this study indicate that there is an influence of arm muscle strength on the accuracy of volleyball smashe obtained thitung $8.256>$ ttabel 2 and significance value of $0.000<0.05$. the result of this study is that the strength of the arm muscles is greater than agility on accuracy of volleyball smashe at aneka clubs in cilegon. This getting the right smash in pratice or competition must be accompanide by arm muscle strength training

@ 2019 Universitas Suryakancana

Alamat korespondensi:

E-mail: Adirahadian@unsur.ac.id
e-ISSN : 2721-7175 (online) p-ISSN : 2089-2341 (cetak) 


\section{PENDAHULUAN}

Permainan bola voli di Indonesia berada di bawah naungan persatuan bola voli seluruh Indonesia atau PBVSI. Sejak Belanda memperkenalkan permainan bola voli, permainan tersebut terus berkembang dan akhirnya sampai setelah Indonesia merdeka permainan voli cukup pesat perkembangannya. Pada tahun 1953 dimana Pekan Olahraga Nasional (PON) III selesai diselenggarakan, Pengurus Ikatan Perhimpunan Volleyball Surabaya (I.P.V.O.S) mengadakan rapat pengurus pada pertengahan tahun 1954. Dalam rapat IPVOS tersebut menghasilkan ide atau keputusan untuk membentuk sebuah organisasi induk bola voli Nasional. Untuk mewujudkan ide tersebut, pengurus IPVOS mengirim seorang untuk menemui pengurus Komite Olimpiade Indonesia (KOI) di Jakarta. Pada waktu itu, atas bantuan dari dokter Aziz Saleh yang merupakan Ketua Komisi Teknik KOI, diadakanlah suatu pertemuan antara IPVOS (Ikatan Perhimpunan Volleyball Surabaya) dan PERVID (Persatuan Volleyball Indonesia Djakarta).

Pertemuan tersebut menghasilkan beberapa keputusan, antara lain: IPVOS dan PERVID menyetujui untuk menjadi sponsor atau perintis dalam mendirikan sebuah top organisasi atau induk organisasi bola voli di Indonesia. Menunjuk bapak Wim J. Latumetan yang merupakan tokoh olahraga sebagai format tunggal dengan tugas menjadi ketua atau pengurus pertama induk organisasi bola voli Indonesia. Kemudian pada 22 januari 1955 diadakan rapat penyusunan pengurus organisasi bola voli Indonesia yang tertinggi tersebut yang bertempat di stadion Ikada Jakarta. Hari itu juga merupakan hari resmi lahirnya induk organisasi bola voli nasional PBVSI (Persatuan Bola Voli Seluruh Indonesia). Dengan susunannya sebagai berikut.

1. Wim J. Latumetan sebagai Ketua

2. Erwin Baharudin sebagai Wakil ketua

3. Soewarno sebagai Penulis dan merangkap bendahara

4. S. Adi Widjaja sebagai Komisi pertandingan

5. Da Graza sebagai Komisi teknik dan pemilih

6. Alimuddin Nasution, Soemadi, R Heinz, Coenraad, W Jocom, dan Soebronto sebagai anggota.

7.W. Kho Kuy Liong sebagai Komisaris daerah yang berkedudukan di surabaya

Pada bulan Maret 1955, PBVSI disahkan oleh KOI sebagai induk organisasi bola voli tertinggi di Indonesia. Pada tahun yang sama itu pula, PBVSI mendapat pengesahan sementara dari IVBF (International Volleyball Federation) yang merupakan induk 
92| Wildan Qohhar ${ }^{1}$, Beni Setiawan ${ }^{2}$, Sandi $^{3}$

Pengaruh Kekuatan Otot Lengan Dengan Kelincahan Terhadap Ketepatan Smash

Bola Voli Pada Club Aneka

organisasi bola voli dunia yang bermarkas besar di Paris, Perancis. Bulan Oktober 1959, PBVSI resmi menjadi anggota IVBF atau sekarang yang dikenal dengan sebutan FIVB. Pada saat itu ada 64 Negara anggota FIVB/ IVBF, dan PBVSI menjadi anggota yang ke 62. PBVSI sejak itu aktif mengembangkan kegiatan-kegiatan baik di dalam maupun ke luar negeri. Perkembangan permainan bola voli sangat menonjol saat menjelang Asian Games IV 1962 dan Ganefo I 1963 di Jakarta, baik untuk putra maupun untuk wanitanya. Dari berbagai ajang tersebut makin menguatkan gairah pervolian di Indonesia. Sebagai dampaknya berbagai klub dan sarana lapangan bola voli sangat mudah dijumpai diberbagai pelosok tanah air. Permainan bola voli ini ternyata diterima dihati masyarakat Indonesia seperti olahraga lain yakni sepak bola dan bulutangkis.

Prestasi yang sudah diraih tim bola voli Indonesia yaitu timnas bola voli Indonesia secara mengejutkan meraih prestasi gemilang dengan menempati peringkat ke empat kejuaraan bola voli senior putra Asia ke-19. Yang berlangsung di Gersik, Jawa Timur, 24 Juli hingga 1 Agustus 2017 lalu. Prestasi ini merupakan sejarah bagi perbolavolian tanah air. Mengingat prestasi terbaik yang pernah ditorehkan timnas bola voli Indonesia adalah peringkat keenam pada kejuaraan Asia di Filipina pada 2009.

Sebelumnya pada 8-15 Juli, timnas putri juga menjadi runner-up turnament bola voli Internasional piala VTV ke-13 di Vietnam. Sukses tim asuhan risco herlambang itu cukup membanggakan karena tim tuan rumah Vietnam yang disiapkan menuju SEA Games XXIX/2017 Kuala Lumpur Malaysia dikalahkan dengan skor 3-2.

Prestasi yang sudah diraih tim bola voli Banten adalah tim bola voli putri kontingen Banten melaju ke babak final pada Pospenas VII tahun 2016 yang dilangsungkan di GOR Maulana Yusuf, Kota serang, rabu (26/10/2016). Tim Banten itu mengalahkan tim bola voli putri dari Jawa Barat dengan kedudukan 3-1, yang cukup menggembirakan. Hal ini terbukti dengan adanya cabang olahraga yang telah meraih prestasi di tingkat nasional dan internasional, salah satu diantaranya adalah cabang olahraga bola voli.

"Permainan bola voli merupakan cabang olahraga beregu yang dimainkan oleh enam orang setiap regu, permainan ini akan berjalan dengan baik apabila setiap pemain minimal telah menguasai teknik dasar bermain bola voli. Teknik dasar permainan bola voli selalu berkembang sesuai dengan perkembangan pengetahuan, teknologi dan ilmu-ilmu yang lain. Adapun teknik dasar dalam permainan bola voli meliputi : (1) passing, (2) smash, (3) servis, (4) umpan, (5) bendungan". Muhajir(2006:8). Permainan bola voli di awali dengan melakukan servis, dengan servis yang menggunakan 
93| Wildan Qohhar ${ }^{1}$, Beni Setiawan ${ }^{2}$, Sandi $^{3}$

Pengaruh Kekuatan Otot Lengan Dengan Kelincahan Terhadap Ketepatan Smash

Bola Voli Pada Club Aneka

teknik yang baik akan dapat membuat lawan kehilangan kontrol pada saat menerima servis dan akan menjadi keuntungan (menambah point) bagi lawan yang melakukan servis. Selain penguasaan teknik dasar yang baik, ada unsur yang tidak kalah pentingnya dalam permainan bola voli. Unsur yang dimaksud adalah unsur kondisi fisik. Kondisi fisik adalah suatu kesatuan utuh dari beberapa komponen yang tidak dapat di pisahkan. Adapun kondisi fisik yang dimaksud adalah kekuatan, daya tahan, daya otot, kecepatan, kelenturan, kelincahan, keseimbangan, ketepatan dan reaksi.

Kekuatan otot lengan dan kelincahan sangat membantu pemain pada saat melakukan smash terutama ketepatan dalam smash. Smash adalah suatu upaya untuk memasukan bola ke daerah lawan oleh pemain depan yang berada di daerah smash, untuk memukul bola dengan satu tangan atau lengan. Bentuk latihan untuk melatih kekuatan otot lengan adalah latihan push-up, chin-up, pull-up dan bertumpu dengan bangku. Latihan ini dapat meningkatkan kemampuan otot lengan.

Pengamatan pada ketepatan smash pada club bola voli Aneka dalam melakukan smash dalam berlangsungnya suatu permainan sering terjadi kesalahan pada saat melakukan smash misalkan bola tidak masuk ke daerah lawan, pukulan smash pemain club Aneka sering keluar lapangan, setelah peneliti mengamati bahwa pemain pada club Aneka terlalu fokus latihan dengan hanya membebani latihan kelincahan saja, mungkin ini merupakan bahwa kekuatan otot lengan terhadap ketepatan smash dalam permainan bola voli club Aneka kurang baik sehingga dalam melakukan smash belum dikuasai dengan maksimal, ketepatan sangat penting dalam permainan bola voli. Mungkin dengan melakukan latihan kekuatan otot lengan akan membantu pemain club Aneka dalam melakukan smash yang baik dan tepat. Kekuatan otot lengan adalah komponen yang sangat penting guna meningkatkan kondisi fisik terutama pada saat melakukan smash, karena dengan kekuatan otot lengan yang dimiliki maka hasil yang didapatpun akan mendapatkan hasil yang baik. Disini penulis ingin memberikan tips atau cara melakukan latihan kekuatan otot lengan. Bentuk latihan untuk melatih kekuatan otot lengan diantaranya latihan push-up, latihan lengan bertumpu pada bangku, pull up, dan chin up. latihan ini dapat meningkatkan kemampuan otot lengan. Menurut Hidayat (2017: 31)“menjelaskan latihan push-up bertujuan meningkatkan kekuatan otot lengan".

Karena dalam melakukan smash jika pemain hanya fokus latihan kelincahan saja masih kurang, karena ada pengaruh lain yang bisa memberikan dampak positif ketika melakukan smash yaitu dengan cara melatih kekuatan otot lengan, dari kekuatan otot lengan dan kelincahan dapat 
94| Wildan Qohhar ${ }^{1}$, Beni Setiawan ${ }^{2}$, Sandi $^{3}$

Pengaruh Kekuatan Otot Lengan Dengan Kelincahan Terhadap Ketepatan Smash

Bola Voli Pada Club Aneka

terlihat dari hasil pukulan smash yang keras dan terarah. Mungkin setelah pemain Aneka melakukan latihan kekuatan otot lengan akan berpengaruh baik bagi setiap pemain agar dapat melakukan smash dengan baik dan terarah.

Jadi kemampuan seorang pemain bola voli untuk memadukan kekuatan otot lengan dan kelincahan sangat diperlukan saat melakukan smash akan berpengaruh terhadap baik buruknya ayunan yang dihasilkan. Smash merupakan salah satu teknik dalam permainan bola voli untuk mendapatkan point bagi tim. Keberhasilan seseorang dalam melakukan smash sangat dipengaruhi oleh Kekuatan otot lengan dan kelincahan..

Berdasarkan uraian diatas, penulis merasa tertarik untuk mengetahui kekuatan otot lengan dan kelincahan yang berpengaruh positif terhadap ketepatan smash dalam permainan bola voli terutama pada club Aneka yang masih banyak melakukan kesalahan dalam melakukan smash yang tidak terarah atau tidak tepat sasaran, sehingga penulis ingin mengangkat penelitian ini dengan judul pengaruh kekuatan otot lengan dengan kelincahan terhadap ketepatan smash dalam bola voli pada club Aneka.

\section{METODE}

Dalam penelitian ini, peneliti mengunakan metode metode experimen. Penelitian exsperimen adalah suatu penelitian yang selalu dilakukan dengan maksud untuk melihat akibat dari suatu perlakuan yang telah diberikan dalam waktu tertentu”. Menurut Arikunto(2010:9). Sehingga dalam penelitian ini dilakukan selama 5 minggu dengan frekuensi 3 kali per minggu dengan waktu 15-25 menit dan terdiri dari 1 kali pertemuan pretest, 14 kali pertemuan untuk treatment dan 1 kali untuk pertemuan posttest.Populasi yang digunakan dalam penelitian ini yaitu seluruh atlit bola voli pada club Aneka yang berjumlah 15 orang laki-laki. Teknik sampling yang digunakan dalam penelitian ini yaitu total sampling. Desain penelitian pretest - posttest control group desain (Sugiyono. 2015:112). Instrumen untuk mengukur self-efficacy dan anxiety yang dimiliki oleh mahasiswa dapat menggunakan kuesioner. Kemudian instrumen tes spike atau smash dari buku Nurhasan (2017 : 225) . Analisis data menggunakan SPSS versi 19.

\section{HASIL dan PEMBAHASAN}

Berdasarkan Model Summary bahwa besarnya hubungan antara selfefficacy dan axienty terhadap hasil tendangan penalti menunjukan korelasi sebesar 0.531 berarti terdapat hubungan dalam katagori sedang. Pada dasarnya selfefficacy maupun axienty keduanya merupakan aspek dalam ilmu psikologis yang sangat penting bagi mental mahasiswa, di mana self-efficacy berfungsi untuk menumbuhkan perasaan yakin 
95| Wildan Qohhar ${ }^{1}$, Beni Setiawan ${ }^{2}$, Sandi $^{3}$

Pengaruh Kekuatan Otot Lengan Dengan Kelincahan Terhadap Ketepatan Smash

Bola Voli Pada Club Aneka

terhadap kemampuan yang dimiliki oleh seorang atlet, sedangkan axienty rendah berfungsi untuk menampilkan kemampuan terbaik atau secara optimal.

\begin{tabular}{|c|c|c|c|c|c|}
\hline Tes & $\begin{array}{c}\text { Kelo } \\
\text { mpok }\end{array}$ & $\begin{array}{c}\text { Th } \\
\mathrm{t}\end{array}$ & $\begin{array}{c}\mathrm{Tt} \\
\mathrm{b}\end{array}$ & $\begin{array}{c}\mathrm{Si} \\
\mathrm{g}\end{array}$ & $\begin{array}{c}\text { Keter } \\
\text { angan }\end{array}$ \\
\hline Pret & Keku & & & & \\
atan & & & & \\
est- & otot & 8. & 2. & 0. & Signi \\
pos & lenga & 25 & 14 & 00 & fikan \\
ttes & $\mathrm{n}$ & 6 & 5 & 0 & \\
$\mathrm{t}$ & Kelin & & & & \\
\cline { 2 - 5 } & cahan & & & & \\
\hline
\end{tabular}

Dari hasil uji-t pada tabel di atas dapat dilihat bahwa thitung 8.256 dan ttabel 2.145 (df 14) dengan nilai signifikasi p sebesar 0.000. oleh karena itu thitung $8.256>$ ttabel 2.145, dan nilai signifikasi $\mathrm{p}$ sebesar $0.000<0.05$, maka hasil ini menunjukan terdapat perbedaan yang signifikan. Artinya kekuatan otot lengan memberikan pengaruh yang signifikan terhadap ketepatan smash. Dari data Pretest memiliki rerata 571.2 dan 658.5, serta standar deviasi sebesar 107.6 dan 241.4. Selanjutnya pada saat Posttest rerata mencapai 602.5 dan 652.8 , serta standar deviasi 138.8 dan 120.0.

Hampir setiap aktifitas teknik dalam permainan bola voli membutuhkan kekuatan.Servis membutuhkan kekuatan pada saat memukul bola, passing atas membutuhkan kekuatan pada saat mendorong bola, smash membutuhkan kekuatan ditambah kecepatan (power) pada saat melakukan pukulan, dengan kata lain kekuatan yang berinteraksi dengan aspek biomotor digunakan dalam permainan bola voli pada saat menampilkan teknik. Melalui temuan ini, diharapkan dapat menjadi bahan evaluasi bagi guru pendidikan jasmani dalam upaya meningkatkan kebugaran jasmani siswa dan memahami betapa pentingnya peran tingkat kebugaran jasmani dalam berbagai kegiatan dalam pendidikan jasmani (Kastrena, dkk, 2020).

\section{SIMPULAN}

Simpulan dalam penelitian ini, kekuatan otot lengan lebih berpengaruh dibandingkan dengan kelincahan terhadap ketepatan smash. Perbedaan yang didapat ketika atlit memiliki kemampuan otot lengan yang maksimal maka atlit dapat melakukan pukulan yang terarah, sedangkan atlit yang memiliki kemampuan kelincahan yang maksimal dapat melakukan koordinasi gerakan langkah dengan ayunan tangan yang baik sehingga dapat melakukan pukulan smash.

\section{DAFTAR PUSTAKA}

Kastrena, E., Suherman, A., Ma'mun, A., Nugraha, E., \&. Nur, L. (2020). Long Jump Ability: A Comparison Between Students with High and Low Physical Fitness. Proceedings of the 4th International Conference 
on Sport Science, Health, and Physical Education (ICSSHPE 2019). Atlantis Press.

Faruq.M,M.(2015).Pengertiandarikelinc ahan.http://bhaguezs26.blogspot. in/2015/1/metode-kepelatihanagility-kelincahan.html?m=1 pada tanggal 23 Mei 2018, 20.53 WIB).

Hapsoro. R. A. (2012). Hubungan power otot tungkai, kelincahan, dan power otot lengan terhadap ketepatan smash semi pada atlet putri unit kegiatan mahasiswa bola voli UNNES tahun 2012.

Hidayat, W. (2017). Buku Pintar Bola Voli. Tim Anugrah Jakarta.

Hudriah, E. (2018). Pengaruh Latihan Kondisi Fisik Terhadap Kelincahan (Agility) Olahraga Permainan di Pusat Pendidikan dan Pelatihan Olahraga Pelajar (PPLP) PROVINSI SULAWESI SELATAN 2018

Istiyadi, A.(2007). Hubungan kekuatan otot lengan dan panjang lengan dengan hasil servis atas bola voli pada siswa putra ekstrakulikuler MA Darul Ma'arif pringapus kab. Semarang. Skripsi pada Universitas Negri Semarang.

Juliantine. T, dan Yudiana. Y. (2017).

Teori Latihan.FPOK UPIRumus Bandung.
Jaedun.A. (2011). Metedologi penelitian eksperimen. Fakultas teknik UNY.

Nurhasan dan Cholil, H. (2017). Tes Dan Pengukuran Keolahragaan. FPOK UPI Bandung.

Nurhasan dan Ruslan (2015). Pengertian kekuatan otot lengan. http://kebugarandanjasmani.blog spot.in/2015/12/ pengertian kekuatan otot lenganmanfaat.html? $\mathrm{m}=1$ pada tanggal 23 Mei 2018, 20.53 WIB.

Pranatahadi dan Suharno (2015). pengertian ketepatan. (online). Tersedia http://kebugaran dan jasmani.blogspot.com / 2015 / 12 / pengertian-ketepaatan-servismanfaat.html. pada tanggal 30 Mei 2018, 20.53 WIB.

Rumus mencari uji normalitas https://www.spssindonesia.com/ 2014/01/uji-normalitaskolmogorov-smirnovspss.html?m=1 pada tanggal 30 juni 2018, 09.30 WIB.

Rumus mencari uji $t$ yaitu : https://www.spssindonesia.com/ 2015/05/cara-uji-independentsample-4-test-dan.html?m=1 pada tanggal 30 juni 2018, 09.47 WIB.

mencari uji homogenitas http://www.spssindonesia.com/2014/02/uj i-homogenitas-dengan-spss.html? $\mathrm{m}=1$ pada tanggal 30 juni 2018, 10.00 WIB. 
97| Wildan Qohhar ${ }^{1}$, Beni Setiawan ${ }^{2}$, Sandi $^{3}$

Pengaruh Kekuatan Otot Lengan Dengan Kelincahan Terhadap Ketepatan Smash

Bola Voli Pada Club Aneka

Rumus mencari mean yaitu : https://www.advernesia.com/blo g/spss/cara-menghitung-meandan-standar-deviasi-denganspss/ pada tanggal 30 juni 2018, 09.05 WIB).

Rumus mencari paired $\mathrm{t}$ test yaitu : https://www.statistikan.com/201 2/07/uji-t-paired-denganspss.html pada tanggal 15 juli 2018, 10.56 WIB.

Rumus mencari independen $t$ test yaitu : https://www.statistikan.com/201 4/04/independen-t-test-denganspss.html pada tanggal 15 juli 2018, 11.30 WIB.

Sedarmayanti dan Hidayat, S. (2011). Metedologi Penelitian. PT Mandar Maju. Bandung.

Sukadiyanto. (2014). Penjasorkes. Quadra.

Suarsan. I. M. (2013), yang berjudul Pengaruh latihan kekuatan otot lengan terhadap ketepatan smash dalam permainan bola voli club Sigma Palu.
Sugiyono. (2015). Metode Penelitian Pendidikan. Bandung. Alfabeta Bandung.

Widiastuti. (2015). Tes Dan Pengukuran Olahraga. PT Rajagrafindo Persada Jakarta.

Wahyu-purwocahyo, M (2013). Hubungan antara kekuatan otot lengan, kekuatan otot punggung, kekuatan otot tungkai dan kordinasi mata, tangan, dengan kemampuan servis atas bola voli siswa putra SMP kanisius gayam Yogyakarta. Skripsi pada Universitas Negri Yogyakarta

Muhamad Syamsul Taufik, 2014 Hubungan Antara Indeks Massa Tubuh, Fleksibilitas Dan Kecepatan Reaksi Dengan Kelincahan Pada

Cabang Olahraga Futsal Lembaga Universitas Pendidikan Indonesia 